\title{
The Spirit of Radio: Hungary 1956, Radio Free Europe, and the Shadow Public Sphere
}

\section{Karl Brown}

\begin{abstract}
This study explores popular responses to communist rule in Hungary and the role of Western media in the years leading up to the Hungarian Revolution of 1956. Most scholars to date have focused on the guiding role of the intelligentsia and the influence of Radio Free Europe. While these were indeed necessary ingredients in the revolutionary stew, Brown argues that the roots of the revolution are more complex. Hungarians from all social strata listened to many Western radio stations; as a result, many of them adopted critical and informed perspectives on the propaganda directed at them from both Moscow and Washington. As Hungarians listened in on the West, their discussion of news and politics generated a shadow public sphere, in which Radio Free Europe came to occupy a preeminent role despite its biased and propagandistic tone. The shadow public sphere incubated the postwar dream of an egalitarian and democratic Hungary until open political discourse became possible once more in October 1956.
\end{abstract}

Keywords: Hungary, 1956, revolution, Radio Free Europe, public sphere

Biography: Karl Brown is an Assistant Professor at the University of Wisconsin - Whitewater. He completed his Ph.D in Modern European History at the University of Texas at Austin with a dissertation entitled "Regulating Bodies: Everyday Crime and Popular Resistance in Communist Hungary, 1948-1956." Karl has published articles on hooliganism and illegal pig-killing, and is currently revising his dissertation for publication as a monograph. brownk@uww.edu

Sixty years on, it might seem there is little left to say about the 1956 Hungarian Revolution. Scholarly analyses appeared at regular intervals throughout the Cold War (see, e.g., Kecskemeti 1961, Molnar 1971, Radványi 1972); since 1989, the opening of the archives has enabled ever-more-accurate recapitulations of the events of October and November of 1956 (see, e.g., Litván 1996, Granville 2004, Eörsi 2001, 2004, 2006, Gati 2006). The main events of the revolution are well-documented: on 23 October 1956, student demonstrations rapidly snowballed into outright rebellion against the communist regime. Imre Nagy (1896-1958) was reinstated as Prime Minister and attempted to appease the demands of both the revolutionaries and the Kremlin in an effort to stave off Soviet intervention. His tightrope act was ultimately ineffective (if, indeed, it ever had any hope of success). On November 4 the Red Army rolled back into Budapest and crushed the revolution. Around 2,500 Hungarians were killed in the fighting; 193,000 more, or roughly $2 \%$ of the population, fled to the West in November and December. Although Western powers loudly condemned the Soviet invasion, they did not intervene: it was 
Brown, Karl. "The Spirit of Radio: Hungary 1956, Radio Free Europe, and the Shadow Public Sphere.” Hungarian Cultural Studies. e-Journal of the American Hungarian Educators Association, Volume 11 (2018) DOI:

an election year in the USA, and Britain and France were occupied with their own imperialist venture in the Suez. Hungary was returned to the Soviet sphere of influence, where it remained until 1989.

Most scholars now concur on the basic goals and causes of the revolution: the revolutionaries sought to abolish communism, but they did not wish to do away entirely with socialism. Nagy and his cohort aspired to a third-road socialism reminiscent of the New Course, or the New Economic Policy of the 1920s in the USSR: "a forerunner to the Prague Spring of 1968 and Mikhail S. Gorbachev's perestroika" (Gati 2006:55). The genesis of revolutionary sentiment is similarly a matter of little debate, as most accounts assert that the intelligentsia were the primary engine of revolt. In the wake of the general amnesty issued in 1953, the crimes committed in the Stalinist era became public knowledge; then, consumed by guilt for having supported the regime, writers and other intellectuals began speaking out against Mátyás Rákosi (1892-1971) and the Party's hardline communists even as they gradually formed an oppositional circle around Nagy. Revolutionary sentiment swelled among the intelligentsia, and was muted but not silenced by Rákosi's return to power in 1955 (Litván 1996:30). In February 1956, Khrushchev delivered his electric secret speech to the Twentieth Party Congress; the text was rapidly leaked, translated, and circulated widely throughout Eastern Europe. Thereafter the tinderbox required only a few sparks - namely the Petőfi Circle debates and the June riots in Poland - to set the revolution ablaze. In short, the conventional narrative of 1956 concentrates primarily on the international context of the revolution and articulate dissent by Nagy and the disaffected intelligentsia.

The effect of Cold War radio broadcasting to Eastern Europe has emerged as a central theme in this historiographical debate. In the 1950s, the struggle for hearts and minds was waged on the airwaves: broadcasts by Radio Free Europe (RFE), Voice of America (VOA), Radio In the American Sector (RIAS) and Armed Forces Network (AFN) augmented the foreign policy and cloak-and-dagger skullduggery of both the Truman and Eisenhower administrations. Most histories of American broadcasting to the Eastern Bloc (many of them written by former employees of American broadcasting organizations) implicitly assume that American stations simply "broadcast freedom," and that Eastern European listeners thereby readily absorbed the evanescent values of liberty, civil society, and democracy (see, e.g., Urban 1997, Puddington 2000, Heil 2003; for more nuanced approaches, see Hixson 1996, Pittaway 2003, Webb 2013). Radio Free Europe was unique among these foreign voices, inasmuch as its architects intended that it serve American foreign policy objectives by taking on the role of "surrogate national stations" for Eastern Bloc countries. To date, most American scholars have considered RFE's role in the 1956 revolution almost entirely from the former standpoint, asking whether Radio Free Europe was somehow "to blame" for the Revolution or the subsequent Soviet crackdown. According to this perspective, RFE's alleged transgressions before and during the revolution (namely, that it insinuated that the West would come to Hungary's aid; that it attacked instead of supported Nagy; and that it consistently goaded the revolutionaries on to more radical demands) had a significant impact on the course of events (Granville 2005: 812, Gati 2006: 142, 183-185, 201). In the most comprehensive analysis to date, Radio Free Europe is largely absolved of guilt: aside from a few incendiary broadcasts (including instruction in partisan warfare tactics) and unduly emotional political commentary during the revolution, RFE seems to have done the best it could in a generally impossible situation (Johnson 2010). Notably, the actual listening 
Brown, Karl. "The Spirit of Radio: Hungary 1956, Radio Free Europe, and the Shadow Public Sphere." Hungarian Cultural Studies. e-Journal of the American Hungarian Educators Association, Volume 11 (2018) DOI:

practices of Hungarians and other Eastern Europeans in the 1950s have remained largely absent from this debate.

My contribution herein is twofold. I argue that the revolutionary goals articulated as a third road to socialism were not transmitted from the intelligentsia down to "the people," but rather in the opposite direction, and I argue that Radio Free Europe (and other Western broadcasters) were catalysts in this process. RFE and other Western stations did not "cause" the revolution in any useful sense; by summer 1956, Hungarians were primed for revolt regardless of what they heard on the radio. However, western broadcasts provided different perspectives and valuable information - about Hungary, the USSR, the USA, and the world at large - that thwarted the communist regimes' attempts at totalitarian control of information behind the Iron Curtain. The net effect of this informed and incessant discussion of politics was the formation of a shadow public sphere, in which the heated political discourse of the immediate postwar erafocusing on topics such as land reform, nationalization, and democratization-was carried on sotto voce beneath the droning buzz of regime-sanctioned discourse. Shaped but not driven by the revolt of the intellectuals in 1953, popular political opposition to the regime then resurfaced with spectacular effect in October 1956.

In the first place, Radio Free Europe was only one among many Western broadcasters to Eastern Europe in the early Cold War. Hungarians listened to many other stations, and many of them were aware of, and wary of, the obvious bias in American broadcasts in general - and Radio Free Europe broadcasts in particular. Like other Eastern Europeans, Hungarians drew on a long tradition of listening to Western broadcasts in formulating their political worldview. They had done so before and during World War II, and they continued doing so in the 1950s.

Although the American stations rapidly became popular, they were relative interlopers in an established media sphere: the British Broadcasting Corporation (BBC) had long been the station of choice for news of world events. Numerous Hungarian (and other Eastern European) listeners recounted listening to RFE, VOA, and AFN; however, they also tuned in to Radio Paris, Radio Monaco, Radio Luxembourg, Radio Madrid, Vatican Radio, and above all the BBC on a regular basis (Kracauer 1956). An audience survey conducted by the US Foreign News Service in early 1953 found that VOA was the most popular station among Eastern European listeners, followed by the BBC and RFE. A follow-up survey in 1954, which focused especially on the reception practices of listeners under age 26, revealed that significant numbers also tuned in to Paris, Madrid, and Rome; almost three-fourths of them also listened to the regime's broadcasts. ${ }^{1}$ In short, Hungarians consumed news, and were the targets of propaganda, from a number of sources: the Soviets, the domestic communist regime, American stations, and a wide variety of western European stations as well.

Radio Free Europe's listenership grew swiftly during the early 1950s, but its burgeoning popularity was not grounded in reliable or objective reporting or commentary. Radio Free

\footnotetext{
${ }^{1}$ The former survey analyzes the reactions of 228 listeners; the latter, 110. In both cases, roughly $1 / 5$ of the respondents were Hungarians. Dwight D. Eisenhower Presidential Library (hereafter 'DEPL') C.D. Jackson Papers, Box 5, Nagorski-Wierzbianski folder, "Survey on Listening Habits Behind the Iron Curtain," n.p., March 1953, and "Reactions of Young Listeners Behind the Iron Curtain to Western Radio Broadcasts," Chart I, 1 February 1954.
} 
Brown, Karl. "The Spirit of Radio: Hungary 1956, Radio Free Europe, and the Shadow Public Sphere.” Hungarian Cultural Studies. e-Journal of the American Hungarian Educators Association, Volume 11 (2018) DOI:

Europe's creators at the CIA, Department of State, and the Office of Policy Coordination (OPC) intended that it operate as an effective tool of US psychological warfare by creating "surrogate national stations" for its captive audiences behind the Iron Curtain. There was no shortage of out-of-work émigrés looking for jobs after World War II, and thus it was possible to staff each national radio - labeled "the Voice of Free Hungary," "the Voice of Free Poland," and so onwith native speakers. Nominally a private organization (albeit largely funded by the CIA until 1967), RFE was not required to demonstrate the nuance or restraint required of the VOA or other official mouthpieces of the American government, and it attacked its Cold War enemy with abandon. Indeed, one contemporary scholar singled out Radio Madrid, the mouthpiece of the authoritarian Franco regime, as the only other station that matched Radio Free Europe's polemics against communism (Kracauer 1956). Among the national radios, the Voice of Free Hungary, staffed by ardent anti-communist émigrés, stood out as more strident and vehement than the Polish or Czechoslovakian Desks (Gati 2006: 101, 102). While RFE's propagandistic tone appealed to some listeners, it also drove many to seek out alternate sources of information.

Many listeners recounted listening to other Western stations specifically in order to gain perspective on Radio Free Europe's biased content. One émigré interviewed in 1957 recounted how he was a regular listener of AFN, RFE and VOA — but also Paris, Madrid, and the BBC, all of which he found more reliable than RFE. Like many of the intelligentsia, he preferred the BBC: "By putting together BBC broadcasts in English, German, and Hungarian I could get a fairly complete picture of world events.... The Paris and Spanish radio were less propagandistic than RFE, but still more than I would have liked." A lawyer from the village of Vámosgyörk reported, "The intelligentsia, or what is left of it, preferes [sic] BBC and VOA, where it can get straight facts and news without the overtone of propaganda which is prevalent in RFE broadcasts." One university-educated listener interviewed in late 1955 delivered this scathing indictment of RFE:

RFE programs contain a lot of propaganda slogans. Its commentators forget that the people in Hungary hear only propaganda slogans from morning until night.... This does not satisfy educated and cultured listeners. If it continues to take this course, RFE will lose even those of its listeners who have only a high-school education. The intelligentsia prefers to listen to $B B C$.

However, it was not only the intelligentsia that listened critically to Radio Free Europe broadcasts. A former textile worker and his wife who escaped in 1953 averred that they liked RFE, but always listened to the BBC and VOA first. One 33-year old farm worker echoed his learned counterpart above almost point for point: 
Brown, Karl. "The Spirit of Radio: Hungary 1956, Radio Free Europe, and the Shadow Public Sphere." Hungarian Cultural Studies. e-Journal of the American Hungarian Educators Association, Volume 11 (2018) DOI:

I think the tone of some RFE programs is too shrill, too sarcastic, and because of this has a propagandistic flavor. People at home are already aware that the louder and more persuasively the regime tries to sell something, the more likely that it is a lie. Thus when they hear the same tone [from RFE], skepticism rears its head: 'They want us to believe so badly, perhaps it's not true. ${ }^{2}$

Thus, not only did many Hungarians listen critically to Radio Free Europe: in its broadcasts, some of them even heard echoes of Radio Budapest or Moscow.

More broadly, Radio Free Europe's credibility gap was common to all American broadcast organizations during the early Cold War. As RFE and VOA were tasked with portraying the United States as the democratic, dialectic opposite of the oppressive Soviet Union, they sought to downplay and even ignore elements of American domestic life that complicated this narrative. However, the 1950s were the era of McCarthyism and the Civil Rights movement, and these newsworthy phenomena were extensively covered by the world and Soviet press. Western Europeans, like thinking people everywhere, saw McCarthyism as a direct threat to American democracy. By 1953, European perceptions of McCarthyism were so negative that it became the focal point of a July meeting of the National Security Council. Recently returned from a trip to Europe, Eisenhower, "informed the Council that he was much disturbed and concerned that so many of our allies seemed frightened of what they imagine the United States government is up to.... The name of McCarthy was on everyone's lips and he was constantly compared to Adolf Hitler." ${ }^{3}$ The Civil Rights Movement was likewise covered extensively in the world and Soviet press, as were the episodic acts of domestic terrorism committed by the $\mathrm{Ku}$ Klux Klan and other racists in defense of the Jim Crow status quo (Dudziak 2003). Confidential briefings prepared by the United States Information Agency repeatedly decried the image problems caused by the murder of Emmett Till, the Montgomery Bus Boycott, and other widely

\footnotetext{
${ }^{2}$ Columbia University Rare Book and Manuscript Archive, Bakhmeteff Archive of Russian and Eastern European Culture, Columbia University Research Project on Hungary (hereafter 'CURPH') Box 7, Interview 102, 57-59; Open Society Archives, Radio Free Europe/Radio Liberty Archives, Information Items HU 300-1-2 (hereafter, 'OSA/RFE Items'), 10200/53, microfilm roll (hereafter ' $\mathrm{mf}$ ') mf 29; OSA/RFE Items 10600/55, mf 61; OSA/RFE Items 11188/53, mf 30; OSA/RFE Items 8316/55, mf 59; see OSA/RFE Items 8316/55, mf 59, and OSA/RFE Items 6464/56, mf 70 for similar statements. A note to researchers: the OSA/RFE Items and the CURPH interviews are two remarkable and underutilized collections of interviews with refugees and émigrés from Hungary. The former were collected on an ad hoc basis from 1951 on, while the latter were conducted en masse in 1957. They are problematic in a number of ways (for instance, the RFE interviewers focused primarily on the propaganda value of the information they collected), but they remain valuable firsthand accounts of everyday life during the early communist period in Hungary - especially for my purposes here, as interviewees were asked specifically about their radio listening habits. Both OSA/RFE and CURPH have been digitized, in their entirety, by the Open Society Archives in Budapest and are now available online at

http://catalog.osaarchivum.org/?f\%5Bdigital_collection\%5D\%5B\%5D=CURPH+Interviews+with+1956+Hungarian +Refugees\&f\%5Brecord_origin_facet\%5D\%5B\%5D=Digital+Repository\&q=1956 and http://catalog.osaarchivum.org/?f\%5Bdigital_collection\%5D\%5B\%5D=RFE+Information+Items\&f\%5Brecord_orig in_facet\%5D\%5B\%5D=Digital+Repository, respectively.

${ }^{3}$ DEPL, Whitman File, National Security Council Series, Box 4, $153^{\text {rd }}$ Meeting of the NSC, 9 July 1953, 11-12.
} 
Brown, Karl. "The Spirit of Radio: Hungary 1956, Radio Free Europe, and the Shadow Public Sphere." Hungarian Cultural Studies. e-Journal of the American Hungarian Educators Association, Volume 11 (2018) DOI:

reported flashpoints of racial tension. ${ }^{4}$ While McCarthyism proved short-lived and some progress was eventually made on the Civil Rights front, during the 1950s these issues rightly complicated American claims to represent a truly democratic order.

Most importantly, Western broadcasts enabled Eastern Europeans to assess communist rule in an objective light. Although all Hungarians interviewed before and after 1956 decried the oppression, surveillance, and terror that accompanied communism in Hungary, many also acknowledged certain beneficial aspects of the system. As one 1956 émigré recounted to her interviewer,

As far as the relationships between equals and subordinates and superiors went, I must emphatically say that the Communists have brought some good to Hungary. They have abolished the tremendous class distinctions that existed before the war. They have abolished the stiffness of relations that one experienced whenever approaching superiors.

A young factory worker who escaped in 1955 singled out the work-training system introduced by the Communists as a particular benefit to Hungarian youths, who had previously been subject to lengthy apprenticeships and social control by their elders (Kürti 2002: 58-62). Another interviewee, a worker and former colonel in the army, found that the expansion of public libraries under the communists was a benefit to cultural life, as "people become used to reading and do not stop at the books selected by the party.... The works of Jókai, Eötvös, Mikszáth, ${ }^{5}$ Balzac, Maupassant, Zola, and Shakespeare can be seen in the hands of real workers and not only those who became unskilled workers under the present regime." He also spoke highly of the various programs geared towards educating and training the youth. Finally, he averred that the bulk of the Hungarian working class felt that

A planned economy is better than free competition because the latter serves only the interests of the capitalists. This means that they only produce profitable goods instead of what the community needs.

Significantly, many of the post-1956 respondents-interviewed in mid-1957, with the memory of the Soviets' bloody crackdown still fresh — echoed these evenhanded perspectives on life under communism. ${ }^{6}$ Rather than disavow every aspect of communist rule, many of its subjects assessed it relatively objectively.

\footnotetext{
${ }^{4}$ See, e.g., National Archives and Research Administration, United States Information Agency, Office of Classified Research, Briefing Reports (Soviet/Satellites), 11 April 1955, 9 January 1956, 19 March 1956. On the KKK in the Hungarian media, see, e.g., “A Ku Klux Klan tagja voltam [I was a Ku Klux Klan Member]” Esti Budapest [Budapest at Night], 14 July 1954.

${ }^{5}$ Mór Jókai (1825-1904), József Eötvös (1831-1871), and Kálmán Mikszáth (1847-1910) were all famous Hungarian writers; the first two were also major figures of the 1848 revolution.

${ }^{6}$ CURPH Interview 108, Box 7, 21-2; OSA/RFE Items 10256/55, mf 61; OSA/RFE Items 11630/55, mf 62; see also, e.g., CURPH, Box 7, Interview 101, 5, and CURPH, Box 10, Interview 152, 278-280.
} 
Brown, Karl. "The Spirit of Radio: Hungary 1956, Radio Free Europe, and the Shadow Public Sphere." Hungarian Cultural Studies. e-Journal of the American Hungarian Educators Association, Volume 11 (2018) DOI:

Critical listening practices coupled with information and perspectives from nonAmerican sources militated against a straightforward acceptance of the RFE line. Many Hungarians listened to Western broadcasts in order to counter the regime's propaganda, then turned to other Western stations in order to debunk the propagandistic content of RFE, VOA and other American broadcast organizations. American broadcasters, and especially RFE, did not simply "broadcast freedom," as one apologist has asserted; however, their presence on the airwaves - coupled with the presence of other Western stations and the critical listening practices detailed above - did have a profound impact on Hungarian political culture.

For critical listeners in Hungary and elsewhere behind the Iron Curtain, non-regime broadcasts served an important function. The unbiased (or rather differently-biased) information of events on both sides of the Iron Curtain provided by foreign media outlets served as grist for the conversational mill around the kitchen table, at work, and in the marketplace. Like other Eastern Europeans, Hungarians often listened to foreign broadcasts in groups, and discussed what they learned from them during work breaks, over meals, and in their spare time. ${ }^{7}$ By staying informed of the issues, by comparing different viewpoints, and by arguing about them in cafés, at home, or on breaks at work, many Hungarians formulated political views independent of either regime or American intentions. As all politics are local, Hungarians applied what they learned from abroad to their particular situation.

The net effect of this informed and incessant discussion, coupled with a deep-seated desire for change, generated what we might usefully label a shadow public sphere.

As Jürgen Habermas defines it, the public sphere emerges in the tension-charged field between the body politic and the government. The public sphere is equal parts argument and agency: as 'the people' discuss political events, the power of the better argument prevails; public opinion, having reached a consensus, then acts as a counterweight to the state's authority. Although Habermas restricts the 'genuine' public sphere to a very specific historical conjuncture (i.e., from 1688 in Britain, 1789 in France, and some unspecified time in Germany, until its "refeudalization" in the mid-nineteenth century), it remains a viable model for analyzing the relationship between popular opinion, the media, and politics in other contexts (Habermas 1991: 54, 62-73, 195). Nancy Fraser (1991) has correctly observed that Habermas' argument glosses over the issue of who is allowed to say what to whom: we must instead conceptualize a complex system of interpenetrating and hierarchical spheres, in which participation (as both senders and receivers) is determined by gender, class, and race. Jean-François Lyotard further notes that the real efficacy of public discourse is dependent not on the crystallization of a hegemonic consensus but rather the articulation of differing viewpoints: as he frames it, "a justice of multiplicity, and a multiplicity of justices" (Lyotard 1984, 1985: 82). To these critiques I would add that Habermas does not adequately address the role of censorship and open access to information: although he

\footnotetext{
${ }^{7}$ These points are agreed upon by most scholars (e.g., Nilson 1997: 64, Kracauer 1956: 128-132), and are borne out by a number of the Items (see, e.g., OSA/RFE Items 11188/53, mf 30 and OSA/RFE Items 2326/56, mf 65 on group listening practices, and OSA/RFE Items 7873/54, mf 43, OSA/RFE Items 3542/55, $\mathrm{mf} 53$, and OSA/RFE 6464/56, $\mathrm{mf} 70$ on group discussions of foreign broadcast content). Oddly, Kracauer found that Hungarians were more prone to discuss the news in groups than Poles or Czechs (Kracauer 1956: 129).
} 
Brown, Karl. "The Spirit of Radio: Hungary 1956, Radio Free Europe, and the Shadow Public Sphere." Hungarian Cultural Studies. e-Journal of the American Hungarian Educators Association, Volume 11 (2018) DOI:

acknowledges the existence of precursor public spheres during the English Civil War and the French Revolution, for him the public sphere only truly operates in regimes that have abolished censorship. As other scholars have argued convincingly that political discourse in both of these periods demonstrate characteristics similar to the public sphere proper (Smith 1994, Darnton 2000), it seems that regime control of media stifles but does not suppress oppositional political discourse. In much this same manner, then, Hungarians in the 1950s carved out a discursive space on the sly: their shadow public sphere was the infrapolitical ${ }^{8}$ equivalent of the uncensored public sphere that operates in non-authoritarian societies.

While this discursive realm was informed by broadcast content from both sides of the Iron Curtain, it was grounded in the all-too-brief postwar democratic experiment. Between 1945 and 1948, Hungary enjoyed a brief spell of democratic coalition government. During the interwar period, stringent property qualifications for the franchise and the absence of secret balloting outside of urban areas (thus, for the majority of the population) had enabled the continued dominance of noble landholders and the urban bourgeoisie. These conservative elites vanished from the political sphere practically overnight as the war ground to a halt (Berend 1998). With no effective censorship, limited Soviet interference, and a slew of political parties (chief among them the Smallholders' Party and the Social Democrats) attempting to capitalize on the new spirit of postwar democratic reform, political life in Hungary assumed a tempestuous and passionate character. From 1945 to late 1947, at least, the public sphere in Hungary was more vibrant, contentious, and inclusive than in any prior period.

Popular discontent during the interwar period had focused primarily on the Horthy regime's aforementioned antidemocratic tendencies and its unwillingness to seriously contemplate breaking up the noble estates. The desired democratization of politics arose organically out of the postwar power vacuum, and land reform was the first and most important issue broached in this new discursive space. Prior to World War II, large noble estates (latifundia) dominated Hungarian agriculture. The wealthiest noble families each controlled over 50,000 cadastral holds; the largest single landholder was the Catholic Church, which held 1.2 million holds. ${ }^{9}$ After 1945, most Hungarians approved of breaking up these estates and distributing the land to the peasantry. Land reform was carried out between 1945 and 1947: over one-third of the country was seized from its prior owners and redistributed to the agrarian poor, most (93\%) of whom had previously farmed five holds or less. At the time, the Hungarian Communist Party (Magyar Kommunista Párt, or MKP) supported this measure as a means of winning over the peasantry to its cause, despite its "regressive" and heretical status in orthodox Marxism. (In this, the MKP was no different from its counterparts throughout postwar Eastern Europe — or, for that matter, the Bolsheviks during the Russian Civil War). However, this

\footnotetext{
${ }^{8}$ On infrapolitics, see Scott 1990: 198-201. I am adopting a narrower definition of 'infrapolitics' herein: I use it to denote the actual articulation of oppositional political stances rather than the vast but mute panoply of "weapons of the weak" he discusses at some length elsewhere (Scott: 1985).

${ }^{9}$ The cadastral hold was the standard unit of land measurement in Hungary between 1851 and World War II. It was .57 hectares, or 1.42 acres, or roughly just over half an ordinary soccer field; as a rule of thumb, one hold would feed one person for one year.
} 
Brown, Karl. "The Spirit of Radio: Hungary 1956, Radio Free Europe, and the Shadow Public Sphere." Hungarian Cultural Studies. e-Journal of the American Hungarian Educators Association, Volume 11 (2018) DOI:

tolerance lasted only until the MKP cemented its control over the government. Collectivization began in earnest in 1948. It was widely resented: peasants who had only recently finally acquired their own land were forced to surrender it, even as the regime silenced all oppositional media.

However, not all aspects of the Communist program were equally unpopular. Unlike land reform, the nationalization of industry was fully in accordance with socialist precepts-but some degree of centralized control was also deemed necessary by most Hungarians well before communist rule was imposed on Hungary in 1948. It enjoyed both precedent and, in the wake of the havoc wrought by World War II, popular support as well. Prior to the war, the Hungarian economy had already been characterized by a high level of state intervention and manipulation, and this trend was only exacerbated during wartime. After decades of depression, occupation, and warfare, a well-planned state appealed to many Europeans as they sought to rebuild after the war (Judt 2000: 38, 75). Many factions in the established capitalist states of Western Europe also supported a planned economy to one or another degree; in this regard, the Hungarian Communist and Social Democratic parties made less strange bedfellows than the Social Democratic and newly-emergent Christian Democratic parties in many western European states.

The initial drive towards the centralization of the Hungarian economy was not a communist innovation: it began under the coalition government, in accordance with popular sentiment. Mines and several major factories were taken over by the state as early as 1946. In November of the next year, the banking system was also nationalized. To return to the broader European context for comparison, even at this point Hungary was no more nationalized than France; the initial version of the Three-Year Plan (1947-1949) "was scarcely more interventionist than France's Monnet Plan" (Judt 2000: 63-77). The communist regime seized power in March 1948, and significantly increased its control over the economy at that time-but mines, major factories, and banks had all been nationalized, by popular consent, during the previous period of coalition government (Swain 1992: 36-38). Although most Hungarians disagreed with the extent to which the Communist Party controlled the economy, a majority concurred that some degree of centralized control was necessary. The imposition of communist rule in 1948 did not end this debate any more than it successfully convinced peasants that giving up their land was necessary. It did, however, make it impossible to conduct this conversation openly.

By any measure Hungary was a police state after 1948. The regime cracked down on all forms of dissent and resistance even as it sought to transform the state into "a country of iron and steel" along Stalinist lines. In the period 1948 to 1956, 1.7 million Hungarians were investigated for crimes ranging from theft to prostitution to hooliganism; over 930,000 of these investigations resulted in convictions (Statisztikai Évkönyv 1949-55, 1957: 355-358, 343-346). These are remarkable numbers for a country that numbered only 9.8 million in 1956 . While political crimes incurred the worst penalties, up to and including torture and death, most of these crimes were of a more quotidian nature: communist Hungary was a state in which one could receive an eight-year prison sentence for illegally slaughtering pigs, a five-year sentence for embezzling funds amounting to less than half an unskilled worker's monthly salary, or a two- 
Brown, Karl. "The Spirit of Radio: Hungary 1956, Radio Free Europe, and the Shadow Public Sphere." Hungarian Cultural Studies. e-Journal of the American Hungarian Educators Association, Volume 11 (2018) DOI:

year sentence simply for uttering a caustic anti-regime remark while standing in a breadline. ${ }^{10}$ Within less than a decade, "there can hardly have been a family in Hungary of which one or more members had not found itself in trouble with the police or state security organs" (Romsics 1999: 273). Although communist rule in Hungary never quite reached the totalitarian degree of control desired by its architects, as various forms of everyday or "passive" resistance ranging from illegal pig-killing to "hooliganism" remained possible (Brown 2007, Horvath 2017), it successfully silenced open opposition throughout the late 1940s and early 1950s.

This changed with Stalin's death in March 1953, as the erosion of Stalinist authority and increased access to foreign broadcasts weakened the communist system and strengthened the shadow public sphere thereafter. As shown above, listeners from all social classes listened to Western broadcasts throughout the entire period despite incessant (albeit mostly ineffective) jamming and the danger of harassment, detention, or arrest if caught. After Stalin's death, Eastern European communist regimes backed off on collectivization, redirected their economies towards consumer goods rather than heavy industry, and released tens of thousands of political prisoners from prisons and labor camps. This destalinzation process was most pronounced in Hungary, where Imre Nagy replaced Mátyás Rákosi as leader. During the "New Course" that ensued, writers and other intellectuals who had previously supported the party now turned against it; they then continued their criticism after Nagy was deposed and Rákosi resumed control in 1955. In doing so, they finally began to echo in regime radio and print media the criticisms of the communist system previously relegated to the shadow public sphere. Also during this period, Hungarians listened to more American and other western broadcasters than ever before, as the number of radio licenses more than doubled between 1951 and 1954, from 539,000 to $1,270,000$. Although most of these radio sets were so-called "people's radios" (Néprádiók), designed to receive only signals broadcast on regime wavelengths, they often picked up foreign stations as well (Pittaway 2003: 99). At the same time, Western broadcasters increased their airtime and programming to Eastern Europe.

Radio Free Europe was at the forefront of this expansion. By 1956, RFE broadcast over eighteen hours per day to Poland, Czechoslovakia, and Hungary-more than three times its closest competitors, the VOA and BBC. While news and commentary comprised the bulk of its output, it also provided music, sport, and entertainment programs. Radio Free Europe augmented its radio broadcasts with a balloon propaganda program, which spread millions of leaflets across the Czechoslovak, Hungarian, and Polish countrysides between 1951 and 1956 (Johnson 2010: 47, 72-73). RFE's extensive intelligence-gathering network ensured that it was usually the first with the news, regularly "scooping" its competitors on key stories such as the 1953 defection of Józef Swiatło (who then became a commentator for the station) and Khrushchev's Secret Speech. The countries behind the Iron Curtain were shaken by Stalin's death, and in making sense of its repercussions their denizens came more and more to rely on western radios, chief among them Radio Free Europe.

\footnotetext{
${ }^{10}$ Hungarian National Archive (Magyar Országos Leveltár, or MOL) M-KS-276. (Archives of the Communist Party) f. 96 (Administrative Office), (Iü) (Legal Division) / 17 ő.e., p. 123, MOL M-KS-276. f. 96 (Iü) / 5 ö.e., p. 134, and MOL M-KS-276. f. 96 (Iü) / 8 ő.e. (2), p. 69a, respectively.
} 
Brown, Karl. "The Spirit of Radio: Hungary 1956, Radio Free Europe, and the Shadow Public Sphere." Hungarian Cultural Studies. e-Journal of the American Hungarian Educators Association, Volume 11 (2018) DOI:

Fueled by foreign media, domestic dissatisfaction inched ever closer to rebellion throughout 1956. The Petöfi Circle, first established as a regime-sanctioned debating society in 1954, pushed the limits of acceptable discourse with its lecture and discussion series throughout early 1956. While it began with cautious criticisms of the party line delivered before small crowds, it rapidly snowballed into riotous mass meetings in which major Party intellectuals such as György Lukács (1885-1971) criticized the regime more openly than ever before. Although the Petöfi Circle was shut down after the tempestuous July 27 meeting on the topic of press freedom, which drew over 6,000 attendants (Hegedüs 1997), many of the criticisms leveled at the regime in the Petöfi Circle formed the basis of the revolutionary demands three months later.

Meanwhile, Khrushchev's Secret Speech in February was followed by the Poznan incident and Rákosi's ouster in June. All these events were covered extensively by Western media. RFE kept up a steady drumbeat of criticism against the regime, repeatedly linking Rákosi with Stalin's worst excesses and predicting his downfall as early as February 20. When the protest at Poznan was crushed by Soviet troops on June 28, Radio Free Europe broadcast this news less than twenty-four hours after it happened. ${ }^{11}$

Finally, on October 23, the public sphere exploded out of the shadows as local voices joined the foreign broadcasters. Revolutionaries took over the Budapest and regional radio stations, broadcasting news from all over Hungary, messages of support from abroad, and other salient information. This was a cacophony rather than a choir. While Radio Budapest served as the mouthpiece of the Nagy government, regional radios such Györ and Miskolcs adopted a divergent and often more radical line. At the same time, many provincial stations broadcast only intermittently; others renamed themselves in revolutionary fashion ("Radio Rajk," "Radio Rakoczi," etc.) both in the spirit of the moment and as a means of eluding capture. Amateur and military shortwave sets also chimed in periodically. Poor journalistic practices abounded, as one should expect during a revolution, and increasingly-desperate rumors of foreign aid joined reports of both real and imagined atrocities as the crisis unwound. Radio Free Europe's entry into this fray led to the charges later leveled against it by its detractors: its commentators failed to deliver their content in a calm and dispassionate tone, it broadcast instructions on anti-tank tactics and partisan warfare, and, most importantly, Radio Free Europe received and retransmitted the broadcasts of these regional stations without identifying them as such (Békés, et. al., ed., 2002: 286-289, Johnson 2010: 91-118). Understandably, given the preeminent role Radio Free Europe had acquired in the years prior, these incidents then dominated memories of the revolution afterwards.

If there is any criticism to be leveled at Radio Free Europe in this crisis situation, it is not for its actions but rather for the Janus-faced contradiction at its core. 1956 revealed that, when pushed to extremes, it was impossible to reconcile RFE's goals as a mouthpiece of American foreign policy with its role as a "surrogate national radio." Even if the USA in the 1950s was a model of democracy - which, as we have seen above, was a problematic claim - the propaganda interests of a global superpower were bound to collide with those of its captive audiences behind

\footnotetext{
${ }^{11}$ Hoover Institute Archives (hereafter 'HIA'), Radio Free Europe/Radio Liberty Broadcast Records 2724.5, Program Summaries Daily Guidance, 20 February 1956, 29 June 1956.
} 
Brown, Karl. "The Spirit of Radio: Hungary 1956, Radio Free Europe, and the Shadow Public Sphere." Hungarian Cultural Studies. e-Journal of the American Hungarian Educators Association, Volume 11 (2018) DOI:

the Iron Curtain. To take just one example, Radio Free Europe's 1951 Policy Handbook proclaimed:

The political or territorial aspirations of spokesmen for ethnic minorities are not a matter for defense by either staff or guest speakers on RFE.... The reason is clear. RFE is a multi-national station. It cannot take a position as between Hungarians and Romanians in the matter of Transylvania, say, or as between Czechs, Ruthenians, and Ukrainians, on the Carpatho-Ruthenian question, without alienating one group of listeners or another to the detriment of its central purpose, which is the liberation of all the peoples it addresses. ${ }^{12}$

This is a common-sense guideline for an American Cold War-era propaganda agency, but would have been anathema to most Hungarians and any radio station they actually controlled. Likewise, any non-American radio (on either side of the Iron Curtain) would have reported more skeptically on Eisenhower's election-year promises not only to contain, but also "roll back" Communism. October 1956, then, stands out as a rare moment at which Radio Free Europe, however inadvertently, responded to the needs of its audience over the intentions of its creators. Broadcasting instructions for partisan warfare was unduly provocative from Washington's standpoint but probably helpful to the youthful warriors in the streets of Budapest; rebroadcasting unidentified regional radio content was similarly a misstep from the American perspective, but in Hungary it added vigor to the revolutionary public sphere as it suddenly surfaced, transcended geography, and sought, however unsuccessfully, to forge a new and revolutionary national identity. In short, it was precisely when Radio Free Europe transgressed its intended purpose as a weaponized form of Cold War media that it lived up to its promise as the Voice of Free Hungary.

During a tense moment in his 1957 interview, one seventeen-year-old peasant émigré cut to the quick with his interlocutor:

In my opinion the West and East like to quarrel with each other. I was interviewed only in order to obtain from me some material with which the United States can spit in the face of Russia again by showing that the Russians were not able to create a better world in Hungary and to maintain peace. Both Russia and America want to govern the whole world. The whole world is only business for them. The Hungarian Revolution and the whole misery of the refugees is only a good business for the West... Why would you take notes of all this material if you would not want to use this for anti-Soviet propaganda? ${ }^{13}$

\footnotetext{
12 "Ethnic Minorities," n.p., in "Radio Free Europe Policy Handbook," 30 November 1951, HIA, Radio Free Europe/Radio Liberty Corporate Records 288.1.

${ }^{13}$ CUHRP Interview 403, Box 13, 37.
} 
Brown, Karl. "The Spirit of Radio: Hungary 1956, Radio Free Europe, and the Shadow Public Sphere." Hungarian Cultural Studies. e-Journal of the American Hungarian Educators Association, Volume 11 (2018) DOI:

As shown by the examples above, this angry young man was not alone in his distrust towards the USA nor his awareness of the ulterior motives afoot. The revolutionary spirit and goals shared by '56ers was the result of neither Western broadcasting to Hungary nor the popular assimilation of the reform intelligentsia project; rather, it was a culmination of political trends carrying through from the brief period of coalition rule, and the largely-uncensored public sphere, of the period between 1945 and 1948. The Hungarian media world of the 1950s was broad and diverse: American stations, especially Radio Free Europe, were treated with caution by many Hungarians, who were quite cognizant of the American stations' biases and ulterior motives. RFE and VOA were indeed important to Hungarian listeners, but so were the BBC and the other dissonant voices from abroad - and these latter, contrapuntal voices agitated against the wholesale assimilation of the biased American product just as the latter provided scathing commentary on the regime's media content. When the writers' revolt finally occurred in 1953, they were joining (or, rather, leaving) the party late. Further complicating Nagy and the intelligentsia's claim to speak for the revolution in 1956 was the fact that the reformers were, by and large, the same people who had been preaching the party line prior to 1953.

The goals of the revolution were dictated by neither the reform intelligentsia nor Radio Free Europe: they were homegrown, and their origin lies in the immediate postwar period. Hungarians did not stop talking or thinking about politics between 1948 and 1956; they merely did so much less openly than before. Eradication of social hierarchy, egalitarian access to education, economic opportunity: these were themes that characterized western broadcasts throughout the period, but they were also supported by Nagy and his reform intelligentsia. On the other hand, the profound wariness of unfettered capitalism and the willingness for the state to retain a significant degree of control over the economy were antithetical to American propaganda. Although some ordinary Hungarians probably did simply buy into the intelligentsia's reform program - much as some of them were doubtless brainwashed by regime propaganda or Radio Free Europe - most of them were simply trying to pick up in 1956 where the ill-starred postwar democratic experiment had left off in 1948. Fueled by information from western broadcasts, the shadow public sphere made possible the stubborn persistence of these political aspirations. Then, in October 1956, after having been silenced for almost a decade, the vox populi finally got the opportunity to talk back.

\section{Works Cited}

Békés, Csaba, Malcolm Byrne, and Janos M. Rainer, editors. 2002. The 1956 Hungarian Revolution: A History in Documents. Budapest: Central European University Press.

Berend, Ivan T. 1998. Decades of Crisis: Central and Eastern Europe before World War II. Berkeley: University of California Press.

Brown, Karl. 2007. "Regulating Bodies: Everyday Crime and Popular Resistance in Communist Hungary, 1948-1956. PhD Dissertation, University of Texas at Austin.

Darnton, Robert. 2000. “An Early Information Society: News and the Media in Eighteenth-Century Paris." The American Historical Review 105 (1): 1-35.

Dudziak, Mary. 2000. Cold War Civil Rights: Race and the Image of American Democracy. Princeton: Princeton UP. 
Brown, Karl. "The Spirit of Radio: Hungary 1956, Radio Free Europe, and the Shadow Public Sphere." Hungarian Cultural Studies. e-Journal of the American Hungarian Educators Association, Volume 11 (2018) DOI:

Eörsi, László. 2006. The Hungarian Revolution of 1956: Myths and Realities. Boulder: Social Science Monographs.

2004. A Szena Tériek 1956 ['The Fighters of Szena Tér']. Budapest: 1956 Institute and State Security Historical Archive.

2001. Corvinisták 1956: A VIII. Kerület fegyveres csoportjai ['The Corvinites, 1956: The Armed Bands of the Eighth District']. Budapest: 1956 Institute.

Fraser, Nancy. 1991. "Rethinking the Public Sphere: A Contribution to the Critique of Actually Existing Democracy." In Habermas and the Public Sphere. Ed. Craig Calhoun.

Cambridge: MIT Press: 109-142.

Gati, Charles. 2006. Failed Illusions: Moscow, Washington, Budapest, and the 1956 Hungarian Revolt. Washington, D.C.: Woodrow Wilson Center Press.

Granville, Joanna. 2004. The First Domino: International Decision Making during the Hungarian Crisis of 1956. College Station: Texas A\&M Press. 2005. "Caught with Jam on our Fingers: Radio Free Europe and the Hungarian Revolution of 1956." Diplomatic History 29 (5): 811-839.

Heil, Alan L. 2003. Voice of America: A History. New York: Columbia UP.

Hegedüs, András. 1997. "The Petofi Circle: The Forum of Reform in 1956." The Journal of Communist Studies and Transition Politics 13 (2): 108-133.

Hixson, Walter L. 1996. Parting the Curtain: Propaganda, Culture, and the Cold War. New York: St. Martin's Press.

Horváth, Sándor. 2017. Stalinism Reloaded: Everyday Life in Stalin-City, Hungary. Bloomington: Indiana UP.

Johnson, A. Ross. 2010. Radio Free Europe and Radio Liberty: The CIA Years and Beyond. Stanford: Stanford UP.

Judt, Tony. 2005. Postwar: A History of Europe Since 1945. New York: Penguin.

Kecskemeti, Paul. 1961. The Unexpected Revolution: Social Forces in the Hungarian Uprising. Stanford: Stanford UP.

Kürti, László. 2002. Youth and the State in Hungary: Capitalism, Communism and Class. London: Pluto Press.

Kracauer, Siegfried. 1956. Satellite Mentality: Political Attitudes and Propaganda Susceptibilities of non-Communists in Hungary, Poland, and Czechoslovakia. New York: Frederick A. Praeger.

Litván, György, ed. 1996. The Hungarian Revolution of 1956: Reform, Revolt, and Repression, 1953-1963. London: Longman.

Lyotard, Jean-François. 1984. The Postmodern Condition. Trans. Geoff Bennington and Brian Massumi, Minneapolis: University of Minnesota Press. with Jean-Loup Thébaud. 1985. Just Gaming. Trans. Wlad Godzich. Minneapolis: University of Minnesota Press.

Molnár, Miklós. 1971. Budapest 1956: A History of the Hungarian Uprising. London: Allen and Unwin.

Nilson, Michael. 1997. The War of the Black Heavens: The Battles of Western Broadcasting During the Cold War. Syracuse: Syracuse UP.

Pittaway, Mark. 2003. "The Education of Dissent: The Reception of the Voice of Free Hungary, 1951-1956." Cold War History IV (1): 97-116. 
Brown, Karl. "The Spirit of Radio: Hungary 1956, Radio Free Europe, and the Shadow Public Sphere." Hungarian Cultural Studies. e-Journal of the American Hungarian Educators Association, Volume 11 (2018) DOI:

2004. "Control and Consent in Eastern Europe's Workers' States, 1949-1989:

Some Reflections on Totalitarianism, Social Organization, and Social Control.” In Social Control in Europe, 1800-2000. Ed. Clive Emsley, Eric Johnson, and Pieter Spierenberg. Columbus: Ohio State UP.

Puddington, Arch. 2000. Broadcasting Freedom: The Cold War Triumph of Radio Free Europe and Radio Liberty. Lexington: The University Press of Kentucky.

Radványi, János. 1972. Hungary and the Superpowers: The 1956 Revolution and Realpolitik. Stanford: Hoover Institution Press.

Romsics, Ignác. 1999. Hungary in the Twentieth Century. Budapest: Corvina/Osiris.

Scott, James C. 1985. Weapons of the Weak: Everyday Forms of Peasant Resistance. New Haven: Yale UP. 1990. Domination and the Arts of Resistance: Hidden Transcripts. New Haven: Yale UP.

Smith, Nigel. 1994. Literature and Revolution in England, 1640-1660. New Haven: Yale UP.

Swain, Nigel. 1992. Hungary: The Rise and Fall of Feasible Socialism. London: Verso.

Statisztikai Évkönyv ['Statistical Yearbook'] 1949-55, 1957. 1957, 1959. Budapest: Központi Statisztikai Hivatal [Central Statistical Office].

Urban, George. 1997. Radio Free Europe and the Struggle for Democracy: My War Within the Cold War. New Haven: Yale UP.

Webb, Alban. 2013. "Cold War Radio and the Hungarian Uprising, 1956." Cold War History 13 (2): 221-238. 